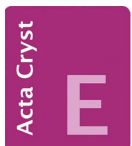

CRYSTALLOGRAPHIC COMMUNICATIONS

ISSN 2056-9890

Received 28 February 2017

Accepted 4 April 2017

Edited by S. Parkin, University of Kentucky, USA

Keywords: crystal structure; cyclodiphosphazane; $\left[\mathrm{EtNP}(\mathrm{S}) \mathrm{NMe}_{2}\right]_{2}$; Hirshfeld surface analysis; fingerprint plots.

CCDC reference: 1015789

Supporting information: this article has supporting information at journals.iucr.org/e

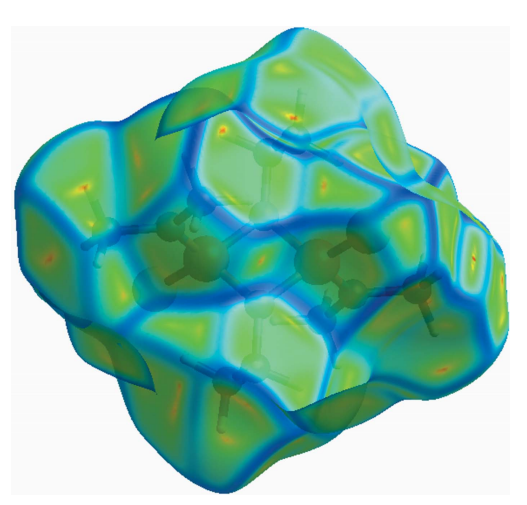

OPEN ๑ ACCESS

\section{Crystal structure and Hirshfeld surface analysis of the new cyclodiphosphazane $\left[\operatorname{EtNP}(\mathrm{S}) \mathrm{NMe}_{2}\right]_{2}$}

\author{
Chokri Issaoui, ${ }^{a}$ Hammouda Chebbi, ${ }^{a}{ }^{a}$ b* Khaled Alouani ${ }^{\mathrm{c}}$ and Abderrahmen \\ Guesmi $^{\mathrm{a}}$
}

\begin{abstract}
a University of Tunis El Manar, Faculty of Sciences of Tunis, Laboratory of Materials, Crystal Chemistry and Applied Thermodynamics, 2092 El Manar II,Tunis, Tunisia, ${ }^{\mathbf{b}}$ Preparatory Institute for Engineering Studies of Tunis, Street Jawaher Lel Nehru, 1089 Montfleury, Tunis, Tunisia, and ${ }^{\mathbf{C}}$ University of Tunis El Manar, Faculty of Sciences of Tunis, Laboratory of Electrochemistry, 2092 El Manar II,Tunis, Tunisia. *Correspondence e-mail: chebhamouda@yahoo.fr
\end{abstract}

The cyclic compound 2,4-bis(dimethylamino)-1,3-diethylcyclodiphosphazane2,4-dithione [systematic name: 2,4-bis(dimethylamino)-1,3-diethyl-1,3,2 $\lambda^{5}, 4 \lambda^{5}$ diazadiphosphetidine-2,4-dithione], $\mathrm{C}_{8} \mathrm{H}_{22} \mathrm{~N}_{4} \mathrm{P}_{2} \mathrm{~S}_{2}$ or $\left[\mathrm{EtNP}(\mathrm{S}) \mathrm{NMe}_{2}\right]_{2}$, is member of a class of molecules that may be used, by virtue of their complexation properties, for the extraction of metals. This compound was characterized in solution by $\left({ }^{1} \mathrm{H}\right.$ and $\left.{ }^{31} \mathrm{P}\right) \mathrm{NMR}$, and in the solid state by energydispersive X-ray spectroscopy (EDX) and by X-ray crystallography. In the crystal, the molecule sits on an inversion centre such that the $\mathrm{P}$ and $\mathrm{N}$ atoms form a centrosymmetric cyclic $\mathrm{P}_{2} \mathrm{~N}_{2}$ arrangement. The crystal packing is dominated by van der Waals interactions. The prevalence of these interactions is illustrated by an analysis of the three-dimensional Hirshfeld surface (HS) and by two-dimensional fingerprint plots (FP). The relative contribution of different interactions to the HS indicates that the $\mathrm{H} \cdots \mathrm{H}$ contacts account for $74.3 \%$ of the total HS area.

\section{Chemical context}

In the study of organophosphorus compounds, one of the aims is to prepare new complexing agents. Indeed, the literature shows many studies of the bidentate organophosphorus ligands $\mathrm{HN}\left[\mathrm{P}(E) \mathrm{R}_{2}\right]_{2}(E: \mathrm{O}, \mathrm{S}$, Se; Balazs et al. 1999; Silvestru et al. 2000; Ghesner et al. 2005; Cristurean et al. 2008) and $R \mathrm{~N}\left[\mathrm{P}(E) \mathrm{R}_{2}\right]_{2}$ (Benabicha et al. 1986; Ladeveze et al. 1986; Alouani et al. 2002, 2007; Peulecke et al. 2009), etc. All of these ligands may act as chelating agents containing both hard (N) and soft (P) elements. In addition, the flexibility of the (EPNPE) system provides a ready means of altering, and thereby possibly improving, their complexing properties. Several complexes based on these ligands have been reported, such as those described by Bennis \& Alouani (2012) and by Mejri et al. (2016).

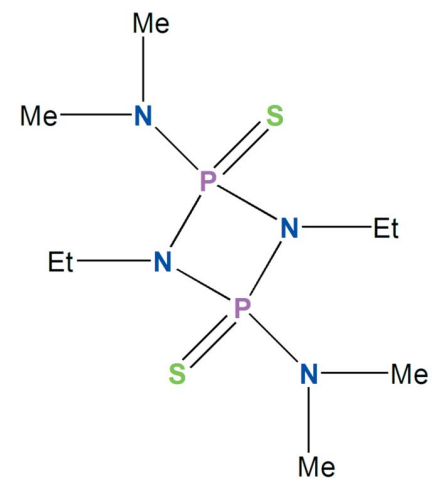




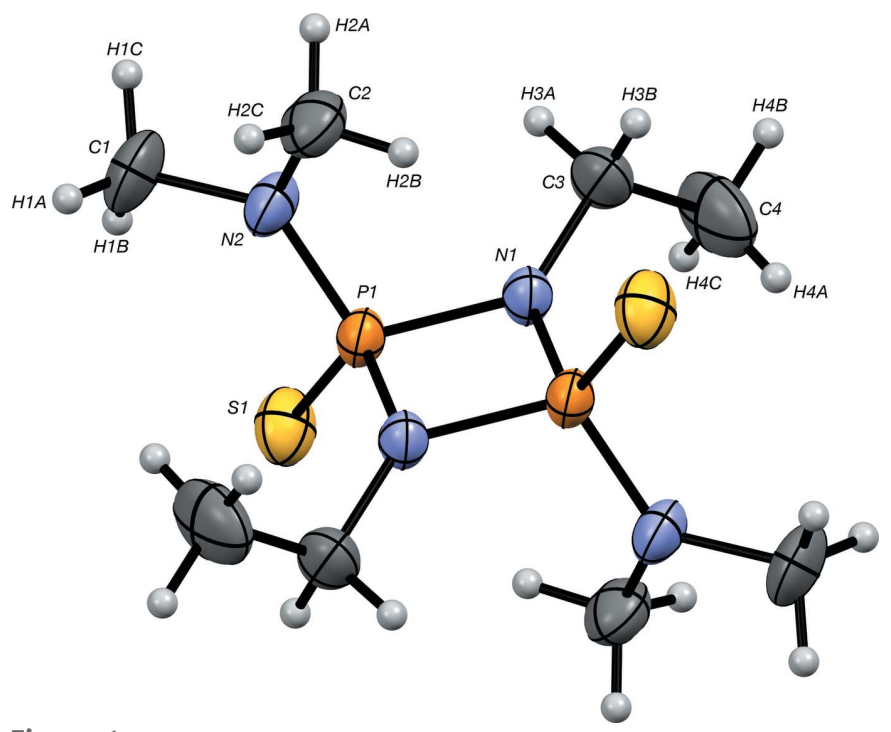

Figure 1

The molecular structure of (I). Atomic displacement parameters for the non-H atoms are drawn at the $30 \%$ probability level. Unlabelled atoms are related to labelled ones by the symmetry operation $-x+1,-y+1$, $-z$.

We report here the synthesis, characterization by $\left({ }^{1} \mathrm{H}\right.$ and ${ }^{31} \mathrm{P}$ ) NMR and energy-dispersive X-ray (EDX) spectroscopies, and a single-crystal structure of a new cyclodiphosphazane, 1,3-diethyl-2,4-dimethylamine-2,4-dithiocyclodiphosphazane, $\left[\mathrm{EtNP}(\mathrm{S}) \mathrm{NMe}_{2}\right]_{2}$ (I). In order to evaluate the nature of the intermolecular interactions in the crystal packing and their associated energies, detailed analyses of Hirshfeld surfaces (HS) and fingerprint plot (FP) calculations were performed (Spackman \& McKinnon, 2002; Parkin et al., 2007; Rohl et al., 2008; Spackman \& Jayatilaka, 2009).

\section{Structural commentary}

The molecular structure of (I) is shown in Fig. 1, selected crystallographic data are presented in Table 1, and an EDX

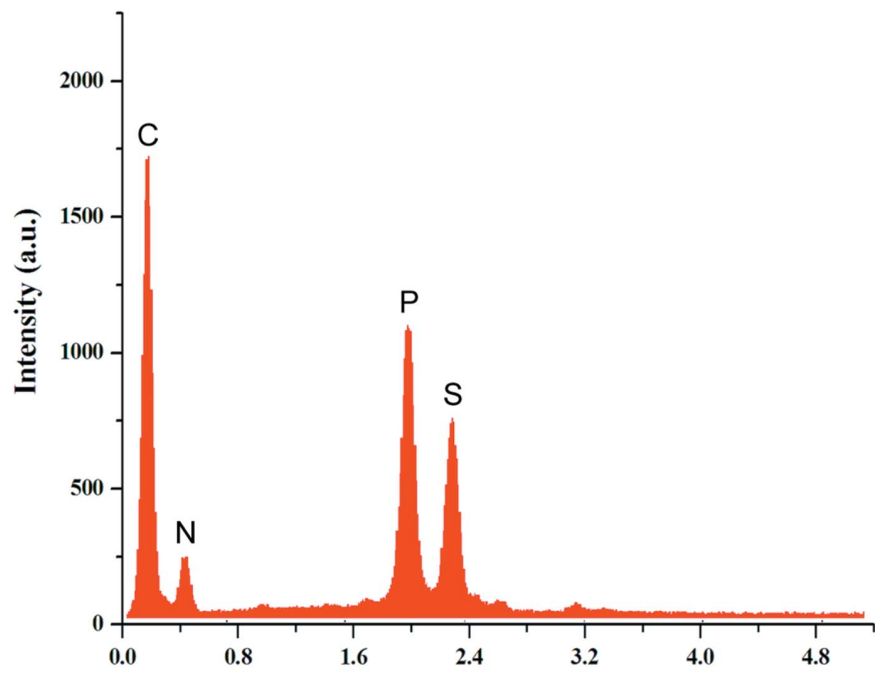

Figure 2

Energy (keV)

The EDX spectrum of (I), showing the presence of C, N, P, and S. spectrum confirming the presence of $\mathrm{C}, \mathrm{N}, \mathrm{P}$ and $\mathrm{S}$ is shown in Fig. 2.

Each phosphorus atom is bonded to one sulfur and three nitrogen atoms, which are linked to methyl or ethyl groups. Atoms $\mathrm{P} 1$ and $\mathrm{N} 1$ form a centrosymmetric cyclic $\mathrm{P}_{2} \mathrm{~N}_{2}$ arrangement about an inversion center $\left(\frac{1}{2}, \frac{1}{2}, 0\right)$. The $\mathrm{P} 1-\mathrm{N} 1$ distances in the ring [1.6856 (17) and 1.6719 (16) $\AA$ ] are longer than the $\mathrm{P} 1-\mathrm{N} 2$ distance [1.6325 (19) $\AA$ ], and the P1-S1 distance is 1.9291 (9) $\AA$. These geometric parameters are in agreement with those observed in related non-cyclic and cyclic neutral ligands (Hill et al., 1994; Alouani et al., 2002; Peulecke et al., 2009; Chandrasekaran et al. 2011).

With regard to the conformation of (I), its structure differs from that of $\mathrm{P}_{2} \mathrm{~S}_{2} \mathrm{~N}_{5} \mathrm{C}_{9} \mathrm{H}_{27}$ (S-NIPA) (Benabicha et al. 1986) primarily by the existence of the $\mathrm{P}_{2} \mathrm{~N}_{2}$ ring. The literature also shows several similar ligands, for example trans$[(\mathrm{EtNH}) \mathrm{P}(\mathrm{S}) \mathrm{NEt}]_{2}$ (Hill et al. 1994) and cis- $\mathrm{P}_{2} \mathrm{~S}_{2} \mathrm{~N}_{4} \mathrm{C}_{20} \mathrm{H}_{42}$ (Chandrasekaran et al. 2011). The most similar known ligand to $(\mathrm{I})$ is the cyclic molecule trans-[(EtNH)P(S)NEt $]_{2}$ (Hill et al. 1994). The two molecules differ in the environments of the nitrogen atoms, which are all bound to ethyl groups in trans$[(\mathrm{EtNH}) \mathrm{P}(\mathrm{S}) \mathrm{NEt}]_{2}$, the peripheral carbons of which are all disordered.

\section{Supramolecular features}

A perspective view of (I) is presented in Fig. 3. Although there are several intra- and intermolecular close contacts of the form $\mathrm{C}-\mathrm{H} \cdots A(A=\mathrm{S}, \mathrm{N})$, no classical hydrogen bonds are found and the dominant interactions are van der Waals contacts.

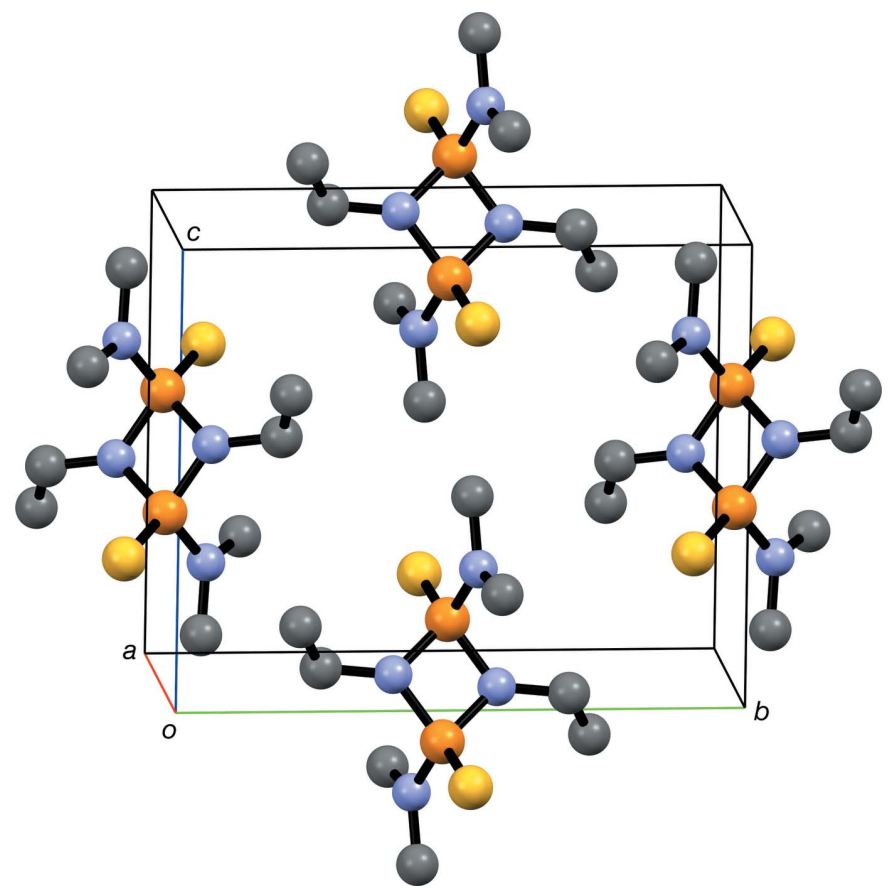

Figure 3

Perspective view of part of the crystal structure of (I), viewed approximately down the $a$ axis. $\mathrm{H}$ atoms have been omitted for clarity. 


\section{Hirshfeld surface analysis}

Organic small molecule crystal packings are often dominated by a particular type of interaction, e.g. hydrogen bonding or van der Waals contacts. However, the overall crystal packing is determined by a combination of many forces, and hence all of the intermolecular interactions of a structure should be taken into account. Visualization and exploration of intermolecular close contacts of a structure is invaluable, and this can be achieved using the Hirshfeld surface (Spackman \& McKinnon, 2002; Spackman \& Jayatilaka, 2009). A large range of properties can be visualized on the Hirshfeld surface with the program CrystalExplorer (Wolff et al., 2012), including $d_{\mathrm{e}}$ and $d_{\mathrm{i}}$, which represent the distances from a point on the HS to the nearest atoms outside (external) and inside (internal) the surface, respectively.

Intermolecular distance information on the surface can be condensed into a two-dimensional histogram of $d_{\mathrm{e}}$ and $d_{\mathrm{i}}$, which is a unique identifier for molecules in a crystal structure, and is known as a fingerprint plot (Parkin et al., 2007; Rohl et al., 2008). Instead of plotting $d_{\mathrm{e}}$ and $d_{\mathrm{i}}$ on the Hirshfeld surface, contact distances are normalized in CrystalExplorer using the van der Waals radius of the appropriate internal $\left(r_{\mathrm{i}}^{\mathrm{vdw}}\right)$ and external $\left(r_{\mathrm{e}}{ }^{\mathrm{vdw}}\right)$ atom of the surface:

$d_{\text {norm }}=\left(d_{\mathrm{i}}-r_{\mathrm{i}}^{\mathrm{vdw}}\right) / r_{\mathrm{i}}{ }^{\mathrm{vdw}}+\left(d_{\mathrm{e}}-r_{\mathrm{e}}^{\mathrm{vdw}}\right) / r_{e}^{\mathrm{vdw}}$.

For (I), the three-dimensional HS mapped over $d_{\text {norm }}$ is given in Fig. 4. Contacts with distances equal to the sum of the van der Waals radii are shown in white, and contacts with distances shorter than or longer than the related sum values are shown in red (highlighted contacts) or blue, respectively. Two-dimensional FP plots showing the occurrence of all kinds of intermolecular contacts are presented in Fig. $5 a$.

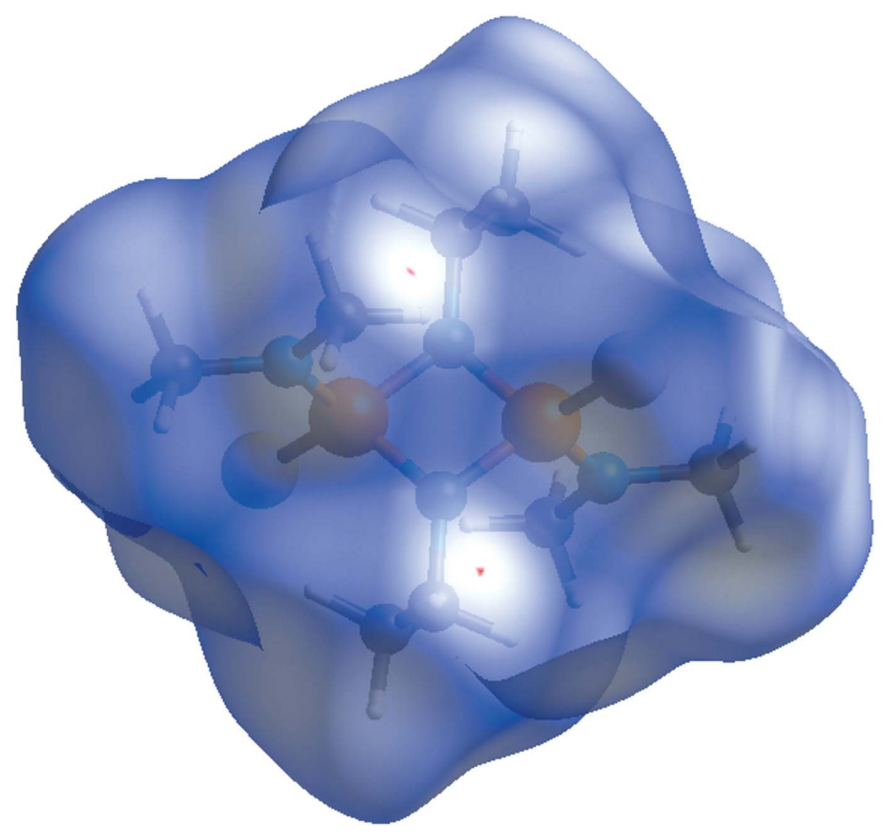

Figure 4

View of the three-dimensional Hirshfeld surface (HS) of (I) mapped with $d_{\text {norm. }}$.

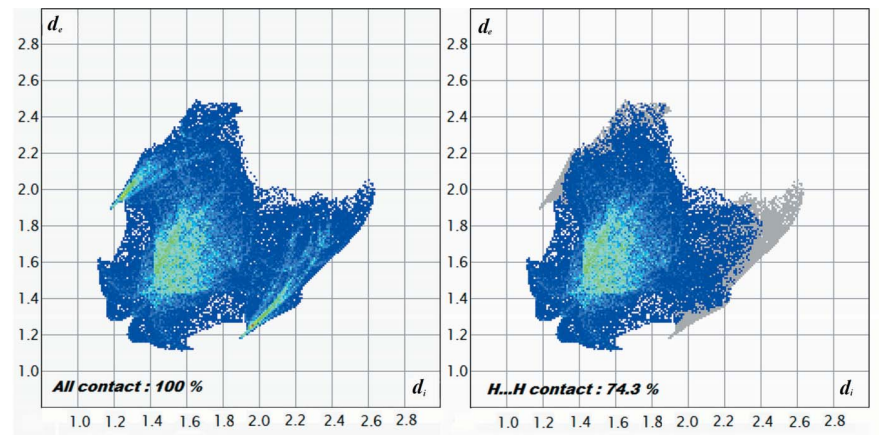

(a)

(b)

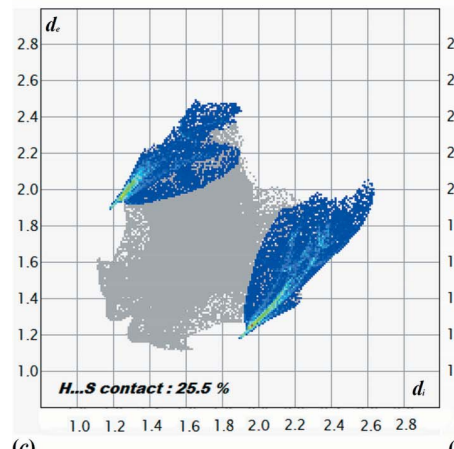

(c)

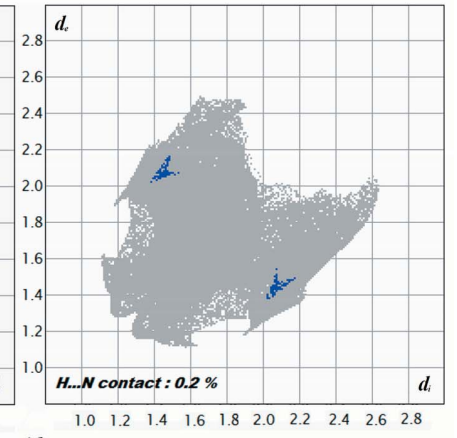

(d)

Figure 5

The two-dimensional fingerprint plots of (I), showing (a) all interactions, and delineated into $(b) \mathrm{H} \cdots \mathrm{H},(c) \mathrm{H} \cdots \mathrm{S}$ and $(d) \mathrm{H} \cdots \mathrm{N}$ interactions $\left[d_{\mathrm{e}}\right.$ and $d_{\mathrm{i}}$ represent the distances from a point on the HS to the nearest atoms outside (external) and inside (internal) the surface, respectively].

The $\mathrm{H} \cdots \mathrm{H}$ interactions are shown on the three-dimensional HS as white spots. These contacts appear in the middle of the scattered points in the two-dimensional FP (Fig. 5b), and represent the most significant contribution to the overall

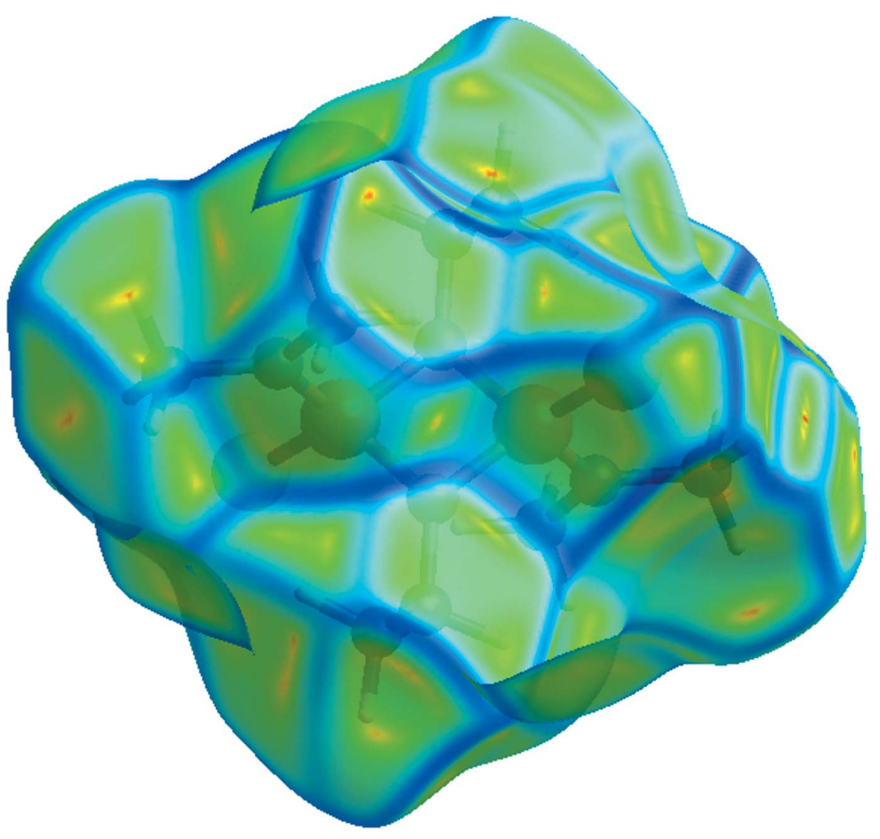

Figure 6

Hirshfeld surface of (I) mapped over curvedness. 
Table 1

Experimental details.

\begin{tabular}{|c|c|}
\hline \multicolumn{2}{|l|}{ Crystal data } \\
\hline Chemical formula & $\mathrm{C}_{8} \mathrm{H}_{22} \mathrm{~N}_{4} \mathrm{P}_{2} \mathrm{~S}_{2}$ \\
\hline$M_{\mathrm{r}}$ & 300.35 \\
\hline Crystal system, space group & Monoclinic, $P 2_{1} / c$ \\
\hline Temperature (K) & 293 \\
\hline$a, b, c(\AA)$ & $7.1975(10), 11.448(2), 9.645(2)$ \\
\hline$\beta\left(^{\circ}\right)$ & $96.39(3)$ \\
\hline$V\left(\AA^{3}\right)$ & $789.8(2)$ \\
\hline$Z$ & 2 \\
\hline Radiation type & Мо $K \alpha$ \\
\hline$\mu\left(\mathrm{mm}^{-1}\right)$ & 0.52 \\
\hline Crystal size $(\mathrm{mm})$ & $0.40 \times 0.40 \times 0.30$ \\
\hline \multicolumn{2}{|l|}{ Data collection } \\
\hline Diffractometer & Enraf-Nonius CAD-4 \\
\hline Absorption correction & $\psi$ scan (North et al.,1968) \\
\hline$T_{\min }, T_{\max }$ & $0.999,1.000$ \\
\hline $\begin{array}{l}\text { No. of measured, independent and } \\
\text { observed }[I>2 \sigma(I)] \text { reflections }\end{array}$ & $3150,1724,1463$ \\
\hline$R_{\text {int }}$ & 0.016 \\
\hline$(\sin \theta / \lambda)_{\max }\left(\AA^{-1}\right)$ & 0.638 \\
\hline \multicolumn{2}{|l|}{ Refinement } \\
\hline$R\left[F^{2}>2 \sigma\left(F^{2}\right)\right], w R\left(F^{2}\right), S$ & $0.041,0.127,1.08$ \\
\hline No. of reflections & 1724 \\
\hline No. of parameters & 76 \\
\hline $\mathrm{H}$-atom treatment & H-atom parameters constrained \\
\hline$\Delta \rho_{\max }, \Delta \rho_{\min }\left(\mathrm{e} \AA^{-3}\right)$ & $0.28,-0.27$ \\
\hline
\end{tabular}

Computer programs: CAD-4 EXPRESS (Duisenberg, 1992; Macíček \& Yordanov, 1992), XCAD4 (Harms \& Wocadlo, 1995), SHELXS97 (Sheldrick, 2008), SHELXL2014/7 (Sheldrick, 2015), Mercury (Macrae et al., 2006), WinGX (Farrugia, 2012) and publCIF (Westrip, 2010).

three-dimensional HS (74.3\%). Significant $\mathrm{H} \cdots \mathrm{S} / \mathrm{S} \cdots \mathrm{H}$ interactions $(25.5 \%)$ can also be seen, indicated by the pair of wings in the two-dimensional FP with a prominent long spike at $d_{\mathrm{e}}+d_{\mathrm{i}} \sim 1.9 \AA$ (Fig. $5 c$ ). The $\mathrm{H} \cdots \mathrm{N} / \mathrm{N} \cdots \mathrm{H}$ interactions are shown on the three-dimensional HS marked with a blue spot for long contacts. These comprise only $0.2 \%$ of the total Hirshfeld surface, and are represented by two symmetrical narrow pointed spikes with $d_{\mathrm{e}}+d_{\mathrm{i}} \sim 2 \AA$ (Fig. $5 d$ ). The presence of these interactions may also be shown by the Hirshfeld surface mapped as a function of curvedness (Fig. 6).

\section{Synthesis and crystallization}

All reagents and solvents were obtained from commercial sources and used without further purification. The synthesis of (I) was carried out in three steps:

- Step 1: Addition of pyridine dropwise to a solution in anhydrous heptane of $2 \mathrm{~mol}$ of $\left(\mathrm{EtNH}_{2} \mathrm{HCl}\right)$ and $2 \mathrm{~mol}$ of $\mathrm{PCl}_{3}$ at $268 \mathrm{~K}$, gave precipitation in the form of a salt. Then, the reaction mixture was refluxed for $24 \mathrm{~h}$. An oil was obtained after filtration of the pyridinium salt and evaporation of the heptane and the excess $\mathrm{PCl}_{3}$. This step corresponds to the formation of $\mathrm{P}_{2} \mathrm{~N}_{2}$ cycle, according to the bibliographic data (Chandrasekaran et al. 2011; Hill et al. 1994). All these operations were conducted under a nitrogen atmosphere to avoid hydrolysis of the chlorinated compounds. The yield of this step is $85 \%$ with respect to ethylammonium chloride.
- Step 2: At a temperature of $263 \mathrm{~K}, 1 \mathrm{~mol}$ of the synthesized $[\mathrm{EtNPCl}]_{2}$ was added dropwise to an ether solution containing $2 \mathrm{~mol}$ of dimethylamine, $2 \mathrm{~mol}$ of triethylamine and 4-dimethylaminopyridine (4-DMAP) as catalyst. After $10 \mathrm{~h}$ of agitation, $\mathrm{Et}_{3} \mathrm{NHCl}$ was precipitated. Filtration of the salt and evaporation of the ether gave an oil. All these operations were conducted under a nitrogen atmosphere. The yield of this step is $40 \%$.

- Step 3: The sulfurization of [EtNPNMe $]_{2}$ with 2 mol of sulfur gave the final product, 1,3-diethyl-2,4-dimethyl-2,4-dithio-cyclodiphosphazane (I), in a yield of about $80 \%$.

Crystallization was carried out from ethanol by slow evaporation at room temperature. After one week, yellow single crystals suitable for X-ray diffraction analysis were obtained. A qualitative EDX analysis on some crystals confirmed the presence of $\mathrm{C}, \mathrm{N}, \mathrm{P}$ and $\mathrm{S}$.

Yield: $(80 \%)$, yellow solid, ${ }^{1} \mathrm{H}$ NMR $\left(300 \mathrm{MHz}, \mathrm{CDCl}_{3}\right): \delta$ (ppm) $1.17\left(t, 1 \mathrm{H},{ }^{3} J_{\mathrm{HH}}=7.26 \mathrm{~Hz}\right), 2.91\left(d, 1 \mathrm{H},{ }^{3} J_{\mathrm{HP}}=12.45 \mathrm{~Hz}\right)$, $3.03(m, 2 \mathrm{H}) ;{ }^{31} \mathrm{P}$ NMR (300 MHz, $\left.\mathrm{CDCl}_{3}\right): \delta(\mathrm{ppm}) 60.13(1 \mathrm{P})$.

\section{Refinement}

Crystal data, data collection and structure refinement details are summarized in Table $1 . \mathrm{H}$ atoms attached to $\mathrm{CH}_{3}$ and $\mathrm{CH}_{2}$ groups were placed geometrically and refined using a riding model: $\mathrm{C}-\mathrm{H}=0.96 \AA$ for $\mathrm{CH}_{3}$ group with $U_{\text {iso }}(\mathrm{H})=1.5 U_{\text {eq }}(\mathrm{C})$ and $\mathrm{C}-\mathrm{H}=0.97 \AA$ for $\mathrm{CH}_{2}$ group with $U_{\text {iso }}(\mathrm{H})=1.2 U_{\text {eq }}(\mathrm{C})$.

\section{Acknowledgements}

Retired Professor Ahmed Driss, University of Tunis El Manar, Faculty of Sciences of Tunis, is thanked for his assistance in the measurement of the X-ray data.

\section{References}

Alouani, K., Guesmi, A. \& Driss, A. (2007). Acta Cryst. E63, o2972. Alouani, K., Rodehuser, L. \& Rubini, P. R. (2002). J. Soc. Alger. Chim. 12, 189-198.

Balazs, G., Drake, J. E., Silvestru, C. \& Haiduc, I. (1999). Inorg. Chim. Acta, 287, 61-71.

Benabicha, F., Courtois, A., Delpuech, J. J., Elkaïm, E., Hubsch, J., Rodehüser, L. \& Rubini, P. (1986). Polyhedron, 5, 2005-2011.

Bennis, M. \& Alouani, K. (2012). Phosphorus Sulfur Silicon, 187, 1490-1497.

Chandrasekaran, P., Mague, J. T. \& Balakrishna, M. S. (2011). Eur. J. Inorg. Chem. pp. 2264-2272.

Cristurean, A., Irisli, S., Marginean, D., Rat, C. \& Silvestru, A. (2008). Polyhedron, 27, 2143-2150.

Duisenberg, A. J. M. (1992). J. Appl. Cryst. 25, 92-96.

Farrugia, L. J. (2012). J. Appl. Cryst. 45, 849-854.

Ghesner, M., Silvestru, A., Silvestru, C., Drake, J. E., Hursthouse, M. B. \& Light, M. E. (2005). Inorg. Chim. Acta, 358, 3724-3734.

Harms, K. \& Wocadlo, S. (1995). XCAD4. University of Marburg, Germany.

Hill, T. G., Haltiwanger, R. C., Thompson, M. L., Katz, S. A. \& Norman, A. D. (1994). Inorg. Chem. 33, 1770-1777.

Ladeveze, G. D., Azad, Y. J., Rodehüser, L., Rubini, P., Selve, C. \& Delpuech, J. J. (1986). Tetrahedron, 42, 371-383. 
Macíček, J. \& Yordanov, A. (1992). J. Appl. Cryst. 25, 73-80.

Macrae, C. F., Edgington, P. R., McCabe, P., Pidcock, E., Shields, G. P., Taylor, R., Towler, M. \& van de Streek, J. (2006). J. Appl. Cryst. 39, 453-457.

Mejri, A., Assili, K. \& Alouani, K. (2016). J. Electroanal. Chem. 767, 134-140.

North, A. C. T., Phillips, D. C. \& Mathews, F. S. (1968). Acta Cryst. A24, 351-359.

Parkin, A., Barr, G., Dong, W., Gilmore, C. J., Jayatilaka, D., McKinnon, J. J., Spackman, M. A. \& Wilson, C. C. (2007). CrystEngComm, 9, 648-652.

Peulecke, N., Aluri, B. R., Wöhl, A., Spannenberg, A. \& Al-Hazmi, M. H. (2009). Acta Cryst. E65, o1084.
Rohl, A. L., Moret, M., Kaminsky, W., Claborn, K., McKinnon, J. J. \& Kahr, B. (2008). Cryst. Growth Des. 8, 4517-4525.

Sheldrick, G. M. (2008). Acta Cryst. A64, 112-122.

Sheldrick, G. M. (2015). Acta Cryst. C71, 3-8.

Silvestru, A., Bîlc, D., Rösler, R., Drake, J. E. \& Haiduc, I. (2000). Inorg. Chim. Acta, 305, 106-110.

Spackman, M. A. \& Jayatilaka, D. (2009). CrystEngComm, 11, 19-32. Spackman, M. A. \& McKinnon, J. J. (2002). CrystEngComm, 4, 378392.

Westrip, S. P. (2010). J. Appl. Cryst. 43, 920-925.

Wolff, S. K., Grimwood, D. J., McKinnon, J. J., Turner, M. J., Jayatilaka, D. \& Spackman, M. A. (2012). Crystal Explorer. University of Western Australia. 


\section{supporting information}

Acta Cryst. (2017). E73, 682-686 [https://doi.org/10.1107/S2056989017005187]

Crystal structure and Hirshfeld surface analysis of the new cyclodiphosphazane $\left[\mathrm{EtNP}(\mathrm{S}) \mathrm{NMe}_{2}\right]_{2}$

\section{Chokri Issaoui, Hammouda Chebbi, Khaled Alouani and Abderrahmen Guesmi}

Computing details

Data collection: CAD-4 EXPRESS (Duisenberg, 1992; Macíček \& Yordanov, 1992); cell refinement: CAD-4 EXPRESS

(Duisenberg, 1992; Macíček \& Yordanov, 1992); data reduction: XCAD4 (Harms \& Wocadlo, 1995); program(s) used to solve structure: SHELXS97 (Sheldrick, 2008); program(s) used to refine structure: SHELXL2014/7 (Sheldrick, 2015); molecular graphics: Mercury (Macrae et al., 2006); software used to prepare material for publication: WinGX (Farrugia, 2012) and publCIF (Westrip, 2010).

2,4-Bis(dimethylamino)-1,3-diethyl-1,3,2 $\lambda^{5}, 4 \lambda^{5}$-diazadiphosphetidine-2,4-dithione

Crystal data

$\mathrm{C}_{8} \mathrm{H}_{22} \mathrm{~N}_{4} \mathrm{P}_{2} \mathrm{~S}_{2}$

$M_{r}=300.35$

Monoclinic, $P 2_{1} / c$

$a=7.1975(10) \AA$

$b=11.448(2) \AA$

$c=9.645(2) \AA$

$\beta=96.39(3)^{\circ}$

$V=789.8(2) \AA^{3}$

$Z=2$

Data collection

Enraf-Nonius CAD-4 diffractometer

Radiation source: fine-focus sealed tube

Graphite monochromator

$\omega / 2 \theta$ scans

Absorption correction: $\psi$ scan

(North et al.,1968)

$T_{\min }=0.999, T_{\max }=1.000$

3150 measured reflections

Refinement

Refinement on $F^{2}$

Least-squares matrix: full

$R\left[F^{2}>2 \sigma\left(F^{2}\right)\right]=0.041$

$w R\left(F^{2}\right)=0.127$

$S=1.08$

1724 reflections
$F(000)=320$

$D_{\mathrm{x}}=1.263 \mathrm{Mg} \mathrm{m}^{-3}$

Mo $K \alpha$ radiation, $\lambda=0.71073 \AA$

Cell parameters from 25 reflections

$\theta=10-15^{\circ}$

$\mu=0.52 \mathrm{~mm}^{-1}$

$T=293 \mathrm{~K}$

Prism, yellow

$0.40 \times 0.40 \times 0.30 \mathrm{~mm}$

1724 independent reflections

1463 reflections with $I>2 \sigma(I)$

$R_{\text {int }}=0.016$

$\theta_{\text {max }}=27.0^{\circ}, \theta_{\min }=2.8^{\circ}$

$h=-9 \rightarrow 4$

$k=-1 \rightarrow 14$

$l=-12 \rightarrow 12$

2 standard reflections every 120 reflections intensity decay: $1 \%$

76 parameters

0 restraints

Hydrogen site location: inferred from neighbouring sites

$\mathrm{H}$-atom parameters constrained 
$w=1 /\left[\sigma^{2}\left(F_{\mathrm{o}}^{2}\right)+(0.0779 P)^{2}+0.1315 P\right]$

where $P=\left(F_{\mathrm{o}}^{2}+2 F_{\mathrm{c}}^{2}\right) / 3$

$(\Delta / \sigma)_{\max }<0.001$

$$
\Delta \rho_{\max }=0.28 \mathrm{e} \AA^{-3}
$$

\section{Special details}

Geometry. All esds (except the esd in the dihedral angle between two 1.s. planes) are estimated using the full covariance matrix. The cell esds are taken into account individually in the estimation of esds in distances, angles and torsion angles; correlations between esds in cell parameters are only used when they are defined by crystal symmetry. An approximate (isotropic) treatment of cell esds is used for estimating esds involving l.s. planes.

Fractional atomic coordinates and isotropic or equivalent isotropic displacement parameters $\left(\hat{A}^{2}\right)$

\begin{tabular}{lllll}
\hline & $x$ & $y$ & $z$ & $U_{\text {iso }} * / U_{\text {eq }}$ \\
\hline P1 & $0.50835(7)$ & $0.50319(4)$ & $0.13083(5)$ & $0.0515(2)$ \\
S1 & $0.33563(10)$ & $0.44283(7)$ & $0.25236(6)$ & $0.0790(3)$ \\
N1 & $0.4319(2)$ & $0.58738(14)$ & $-0.00532(16)$ & $0.0535(4)$ \\
N2 & $0.6900(3)$ & $0.56638(18)$ & $0.21583(18)$ & $0.0670(5)$ \\
C1 & $0.7415(5)$ & $0.5568(3)$ & $0.3657(3)$ & $0.0952(9)$ \\
H1A & 0.8411 & 0.5013 & 0.3838 & $0.143^{*}$ \\
H1B & 0.6352 & 0.5313 & 0.4096 & $0.143^{*}$ \\
H1C & 0.7821 & 0.6316 & 0.4024 & $0.143^{*}$ \\
C2 & $0.8350(4)$ & $0.6172(3)$ & $0.1411(3)$ & $0.0814(7)$ \\
H2A & 0.8611 & 0.6952 & 0.1740 & $0.122^{*}$ \\
H2B & 0.7932 & 0.6190 & 0.0431 & $0.122^{*}$ \\
H2C & 0.9465 & 0.5708 & 0.1569 & $0.122^{*}$ \\
C3 & $0.3911(4)$ & $0.7123(2)$ & $-0.0151(3)$ & $0.0779(7)$ \\
H3A & 0.4058 & 0.7454 & 0.0781 & $0.093^{*}$ \\
H3B & 0.4816 & 0.7496 & -0.0679 & $0.093^{*}$ \\
C4 & $0.2046(5)$ & $0.7387(3)$ & $-0.0806(5)$ & $0.1204(13)$ \\
H4A & 0.1842 & 0.7000 & -0.1692 & $0.181^{*}$ \\
H4B & 0.1921 & 0.8216 & -0.0940 & $0.181^{*}$ \\
H4C & 0.1139 & 0.7121 & -0.0218 & $0.181^{*}$ \\
\end{tabular}

Atomic displacement parameters $\left(\AA^{2}\right)$

\begin{tabular}{lllllll}
\hline & $U^{11}$ & $U^{22}$ & $U^{33}$ & $U^{12}$ & $U^{13}$ & $U^{23}$ \\
\hline P1 & $0.0546(3)$ & $0.0576(3)$ & $0.0405(3)$ & $0.0050(2)$ & $-0.0029(2)$ & $0.00125(18)$ \\
S1 & $0.0763(4)$ & $0.1040(5)$ & $0.0580(4)$ & $-0.0017(3)$ & $0.0128(3)$ & $0.0143(3)$ \\
N1 & $0.0607(9)$ & $0.0518(8)$ & $0.0455(8)$ & $0.0091(7)$ & $-0.0047(6)$ & $0.0007(6)$ \\
N2 & $0.0686(11)$ & $0.0823(12)$ & $0.0463(8)$ & $-0.0038(9)$ & $-0.0108(8)$ & $-0.0049(8)$ \\
C1 & $0.099(2)$ & $0.130(2)$ & $0.0502(12)$ & $-0.0017(18)$ & $-0.0202(13)$ & $-0.0108(14)$ \\
C2 & $0.0660(13)$ & $0.0974(18)$ & $0.0771(15)$ & $-0.0159(13)$ & $-0.0078(11)$ & $-0.0025(14)$ \\
C3 & $0.0919(17)$ & $0.0540(11)$ & $0.0833(15)$ & $0.0127(11)$ & $-0.0097(13)$ & $-0.0028(11)$ \\
C4 & $0.091(2)$ & $0.087(2)$ & $0.178(4)$ & $0.0302(17)$ & $-0.007(2)$ & $0.038(2)$
\end{tabular}

Geometric parameters $\left(A,{ }^{\circ}\right)$

\begin{tabular}{llll}
\hline $\mathrm{P} 1-\mathrm{N} 2$ & $1.6325(19)$ & $\mathrm{C} 1-\mathrm{H} 1 \mathrm{C}$ & 0.9600 \\
$\mathrm{P} 1-\mathrm{N} 1$ & $1.6719(16)$ & $\mathrm{C} 2-\mathrm{H} 2 \mathrm{~A}$ & 0.9600
\end{tabular}




\begin{tabular}{|c|c|c|c|}
\hline $\mathrm{P} 1-\mathrm{N} 1^{\mathrm{i}}$ & $1.6856(17)$ & $\mathrm{C} 2-\mathrm{H} 2 \mathrm{~B}$ & 0.9600 \\
\hline $\mathrm{P} 1-\mathrm{S} 1$ & $1.9291(9)$ & $\mathrm{C} 2-\mathrm{H} 2 \mathrm{C}$ & 0.9600 \\
\hline $\mathrm{P} 1-\mathrm{P} 1^{\mathrm{i}}$ & $2.5143(10)$ & $\mathrm{C} 3-\mathrm{C} 4$ & $1.450(4)$ \\
\hline $\mathrm{N} 1-\mathrm{C} 3$ & $1.460(3)$ & $\mathrm{C} 3-\mathrm{H} 3 \mathrm{~A}$ & 0.9700 \\
\hline $\mathrm{N} 1-\mathrm{P} 1^{\mathrm{i}}$ & $1.6857(17)$ & $\mathrm{C} 3-\mathrm{H} 3 \mathrm{~B}$ & 0.9700 \\
\hline $\mathrm{N} 2-\mathrm{C} 2$ & $1.455(3)$ & $\mathrm{C} 4-\mathrm{H} 4 \mathrm{~A}$ & 0.9600 \\
\hline $\mathrm{N} 2-\mathrm{C} 1$ & $1.456(3)$ & $\mathrm{C} 4-\mathrm{H} 4 \mathrm{~B}$ & 0.9600 \\
\hline $\mathrm{C} 1-\mathrm{H} 1 \mathrm{~A}$ & 0.9600 & $\mathrm{C} 4-\mathrm{H} 4 \mathrm{C}$ & 0.9600 \\
\hline $\mathrm{C} 1-\mathrm{H} 1 \mathrm{~B}$ & 0.9600 & & \\
\hline $\mathrm{N} 2-\mathrm{P} 1-\mathrm{N} 1$ & $108.31(10)$ & $\mathrm{H} 1 \mathrm{~B}-\mathrm{C} 1-\mathrm{H} 1 \mathrm{C}$ & 109.5 \\
\hline $\mathrm{N} 2-\mathrm{P} 1-\mathrm{N} 1^{\mathrm{i}}$ & $112.28(10)$ & $\mathrm{N} 2-\mathrm{C} 2-\mathrm{H} 2 \mathrm{~A}$ & 109.5 \\
\hline $\mathrm{N} 1-\mathrm{P} 1-\mathrm{N} 1^{\mathrm{i}}$ & $83.02(8)$ & $\mathrm{N} 2-\mathrm{C} 2-\mathrm{H} 2 \mathrm{~B}$ & 109.5 \\
\hline $\mathrm{N} 2-\mathrm{P} 1-\mathrm{S} 1$ & $112.81(8)$ & $\mathrm{H} 2 \mathrm{~A}-\mathrm{C} 2-\mathrm{H} 2 \mathrm{~B}$ & 109.5 \\
\hline $\mathrm{N} 1-\mathrm{P} 1-\mathrm{S} 1$ & $120.38(7)$ & $\mathrm{N} 2-\mathrm{C} 2-\mathrm{H} 2 \mathrm{C}$ & 109.5 \\
\hline $\mathrm{N} 1{ }^{\mathrm{i}}-\mathrm{P} 1-\mathrm{S} 1$ & $116.69(7)$ & $\mathrm{H} 2 \mathrm{~A}-\mathrm{C} 2-\mathrm{H} 2 \mathrm{C}$ & 109.5 \\
\hline $\mathrm{N} 2-\mathrm{P} 1-\mathrm{P} 1^{\mathrm{i}}$ & $117.58(8)$ & $\mathrm{H} 2 \mathrm{~B}-\mathrm{C} 2-\mathrm{H} 2 \mathrm{C}$ & 109.5 \\
\hline $\mathrm{S} 1-\mathrm{P} 1-\mathrm{P} 1^{\mathrm{i}}$ & $129.60(4)$ & $\mathrm{C} 4-\mathrm{C} 3-\mathrm{N} 1$ & $113.7(2)$ \\
\hline $\mathrm{C} 3-\mathrm{N} 1-\mathrm{P} 1$ & $131.38(16)$ & $\mathrm{C} 4-\mathrm{C} 3-\mathrm{H} 3 \mathrm{~A}$ & 108.8 \\
\hline $\mathrm{C} 3-\mathrm{N} 1-\mathrm{P} 1^{\mathrm{i}}$ & $128.43(17)$ & $\mathrm{N} 1-\mathrm{C} 3-\mathrm{H} 3 \mathrm{~A}$ & 108.8 \\
\hline $\mathrm{P} 1-\mathrm{N} 1-\mathrm{P} 1^{\mathrm{i}}$ & $96.98(8)$ & $\mathrm{C} 4-\mathrm{C} 3-\mathrm{H} 3 \mathrm{~B}$ & 108.8 \\
\hline $\mathrm{C} 2-\mathrm{N} 2-\mathrm{C} 1$ & $113.9(2)$ & $\mathrm{N} 1-\mathrm{C} 3-\mathrm{H} 3 \mathrm{~B}$ & 108.8 \\
\hline $\mathrm{C} 2-\mathrm{N} 2-\mathrm{P} 1$ & $120.47(15)$ & $\mathrm{H} 3 \mathrm{~A}-\mathrm{C} 3-\mathrm{H} 3 \mathrm{~B}$ & 107.7 \\
\hline $\mathrm{C} 1-\mathrm{N} 2-\mathrm{P} 1$ & $124.5(2)$ & $\mathrm{C} 3-\mathrm{C} 4-\mathrm{H} 4 \mathrm{~A}$ & 109.5 \\
\hline $\mathrm{N} 2-\mathrm{C} 1-\mathrm{H} 1 \mathrm{~A}$ & 109.5 & $\mathrm{C} 3-\mathrm{C} 4-\mathrm{H} 4 \mathrm{~B}$ & 109.5 \\
\hline $\mathrm{N} 2-\mathrm{C} 1-\mathrm{H} 1 \mathrm{~B}$ & 109.5 & $\mathrm{H} 4 \mathrm{~A}-\mathrm{C} 4-\mathrm{H} 4 \mathrm{~B}$ & 109.5 \\
\hline $\mathrm{H} 1 \mathrm{~A}-\mathrm{C} 1-\mathrm{H} 1 \mathrm{~B}$ & 109.5 & $\mathrm{C} 3-\mathrm{C} 4-\mathrm{H} 4 \mathrm{C}$ & 109.5 \\
\hline $\mathrm{N} 2-\mathrm{C} 1-\mathrm{H} 1 \mathrm{C}$ & 109.5 & $\mathrm{H} 4 \mathrm{~A}-\mathrm{C} 4-\mathrm{H} 4 \mathrm{C}$ & 109.5 \\
\hline $\mathrm{H} 1 \mathrm{~A}-\mathrm{C} 1-\mathrm{H} 1 \mathrm{C}$ & 109.5 & $\mathrm{H} 4 \mathrm{~B}-\mathrm{C} 4-\mathrm{H} 4 \mathrm{C}$ & 109.5 \\
\hline
\end{tabular}

Symmetry code: (i) $-x+1,-y+1,-z$. 